\title{
THE ASSOCIATION BETWEEN GUIDED IMAGERY USING CLASSICAL MUSIC ON PAIN LEVEL AMONG POST FRACTURE PATIENTS
}

\author{
Candra Kusuma Negara, Murjani, Anna Martiana, Fajar Kurniawan
}

School of Health Science Cahaya Bangsa Banjarmasin

\begin{abstract}
Background: Bone fracture, also known as a broken bone, is a condition that changes the contour (shape) of the bone. Fractures often occur when there is a high force or impact put on a bone. Acute pain usually occurs immediately after the fracture when the bone has broken. Method of handling the pain that can be done is the non-pharmacological techniques that provide guided imagery through the use of classical music. This study aimed to investigate the association between guided imagery using classical music on pain level among post fracture patients.

Subjects and Method: This was a quasi-experimental study conducted at Nuri Room of Idaman Hospital Banjarbaru, South Kalimantan. A total of 22 patients of post-fracture surgery who were experiencing pain was selected for this study. The dependent variable was pain. The independent variable was guided imagery using classical music. The data of pain were measured by Visual Analog Scale (VAS) observation sheets. The data were analyzed by Wilcoxon test.

Results: The mean difference of pain was lower after the intervention of guided imagery using classical music, than before the intervention, and it was statistically significant $(\mathrm{p}<0.001)$.

Conclusion: Guided imagery using classical music can reduce pain among patients of post-fracture surgery.

Keywords: guided imagery, classical music, pain, post-fracture surgery

Correspondence:

Candra Kusuma Negara. School of Health Science Cahaya Bangsa Banjarmasin, South Kalimantan. Email: cknegara@stikescb.ac.id. Mobile: 085252852701.
\end{abstract}

The $6^{\text {th }}$ International Conference on Public Health

Best Western Premier Hotel, Solo, Indonesia, October 23-24, 2019 | 354

https://doi.org/10.26911/the6thicph.05.19 